\title{
Article
}

\section{Judicial Review, Irrationality, and the Legitimacy of Merits-Review}

Turner, Ian David

Available at http://clok.uclan.ac.uk/8960/

Turner, Ian David ORCID: 0000-0002-8012-1480 (2008) Judicial Review, Irrationality, and the Legitimacy of Merits-Review. Liverpool Law Review, 29 (3). pp. 309-333. ISSN 0144-932X

It is advisable to refer to the publisher's version if you intend to cite from the work. http://dx.doi.org/10.1007/s10991-008-9047-4

For more information about UCLan's research in this area go to http://www.uclan.ac.uk/researchgroups/ and search for < name of research Group>.

For information about Research generally at UCLan please go to http://www.uclan.ac.uk/research/

All outputs in CLoK are protected by Intellectual Property Rights law, including Copyright law. Copyright, IPR and Moral Rights for the works on this site are retained by the individual authors and/or other copyright owners. Terms and conditions for use of this material are defined in the policies page.

\section{CLoK}

Central Lancashire online Knowledge www.clok.uclan.ac.uk

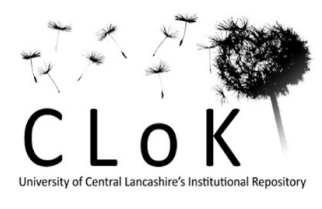




\title{
Judicial Review, Irrationality, and the Legitimacy of Merits-Review
}

\section{Ian Turner*}

Ian Turner

Senior Lecturer in Law

The Lancashire Law School

The University of Central Lancashire

Preston PR1 2HE

idturner@uclan.ac.uk

\begin{abstract}
The definition of the irrationality ground of judicial review recognises the constitutional principle of the separation of powers, in allowing for judicial control of the executive only very rarely. The author in a previous article in this study found that the courts, on occasions, had intervened in circumstances where administrative decisions arguably were not irrational. To this end, the purpose of this article is to assess the constitutionality of these seemingly low standards of irrationality. The author does so by reference either to the manner of review employed - the use of the proportionality principle, for example - or the context of the administrative decision under scrutiny, such as the infringement of the applicant's fundamental rights. The author finds that the cases from the previous article where low standards of irrationality were arguably adopted were, in fact, legitimate according to these chosen methods of evaluation. However, this is an interim conclusion because, for reasons of word length, the author is unable to complete a full assessment here. It is therefore proposed that a subsequent article will continue to examine the constitutionality of these cases. Furthermore, the author will also try and establish a zone of executive decision-making, for reasons of democracy, where the courts are excluded from irrationality review. If the author is unsuccessful in this regard, the final conclusion of this study will inevitably be that low standards of judicial intervention exist without limit - a clear assault on the constitutional principle stated above.
\end{abstract}

\footnotetext{
${ }^{*}$ The author wishes to thank Michael Salter, Stuart Toddington and Steve Foster for comments on earlier drafts of this article. The author is, of course, responsible for any errors or omissions.
} 


\section{Key Words}

Judicial Review, Legitimacy of Merits-Review, Irrationality, Proportionality, “Hard Look”, “Anxious Scrutiny”, Intensity of Review, the Human Rights Act 1998, the ECHR and "Qualified” rights.

\section{Introduction}

Orthodox theories of administrative law prescribe that judicial review is concerned with examining only the legality of executive power rather than its merits. ${ }^{1}$ For example, Lord Irvine, a previous Lord Chancellor, has identified at least three justifications for this principle. First, 'a constitutional imperative': public authorities should exercise discretionary powers that have been entrusted to them by Parliament. Every authority has within its influence a level of knowledge and experience which justifies the decision of Parliament to entrust that authority with decision-making power. Second, 'lack of judicial expertise': it follows that the courts are ill-equipped to take decisions in place of the designated authority. Third, 'the democratic imperative': it has long been recognised that elected public authorities, and particularly local authorities, derive their authority in part from their electoral mandate. ${ }^{2}$ These imperatives of judicial restraint owe much, therefore, to the constitutional principle of the separation of powers between the organs of the state. ${ }^{3}$ Though this principle has never been strictly enforced in the UK, ${ }^{4}$ the tenets of such a philosophy arguably still hold true. ${ }^{5}$ Indeed, this principle has been strengthened in recent years with the coming into force of the Human Rights Act 1998 (HRA), incorporating certain Articles of the European Convention on Human Rights (ECHR), ${ }^{6}$ such as Article 6, the right to a fair trial by an independent and unbiased

\footnotetext{
${ }^{1}$ See S. De Smith et al (1999, p.20).

${ }^{2}$ Irvine (1999, pp.60-61). Note: Lord Irvine rejected the review of merits where the courts were employing principles of the common law (such as irrationality), but later accepted it when they were applying the proportionality test to certain breaches of the European Convention on Human Rights (ECHR) - see Irvine (1998, p.229) and (2003, p.313).

${ }^{3}$ See Montesquieu (1994, Chapter XI, pp.3-6).

${ }^{4}$ See, for example, Barendt (1995) and Barber (2001).

${ }^{5}$ See, for example, Hoffman (2002) and Steyn (2002).

${ }^{6}$ The Human Rights Act 1998 s.1 labels Articles 2-12 and 14 of the European Convention on Human Rights (ECHR), Articles 1-3 of the $1^{\text {st }}$ Protocol of the ECHR and Protocol 13 of the ECHR as 'Convention rights'.
} 
tribunal, into UK Law and the Constitutional Reform Act 2005 (CRA), section 3 of which upholds the independence of the judiciary.

Nevertheless, is this traditional legal theory that the courts' role is to assess only the lawfulness of administrative action still true in practice? In a previous article the author sought to answer this very question. ${ }^{7}$ He analysed several cases where the courts had ruled that the administrative body in question had acted contrary to the principle of Wednesbury unreasonableness/irrationality, ${ }^{8}$ but found that the case facts did not arguably support judicial intervention. In this regard the standards of irrationality adopted caused the judges to review the merits of the decision under consideration. ${ }^{9}$ In concluding that this finding was an anathema to established principles of public law, the author questioned whether this orthodox theory about judicial review’s supervisory nature was a constitutional “fig leaf”, disguising yet another fiction of administrative law ${ }^{10}$

If in reality this traditional notion of judicial review is not always being employed by the courts in practice, what then are the consequences of this in the modern era? As a student of administrative law schooled in the 'green light'11/ political constitutionalist traditions of John Griffith, ${ }^{12}$ Patrick McAuslan ${ }^{13}$ and others - that is, a deep suspicion

\footnotetext{
${ }^{7}$ Turner (2006).

${ }^{8}$ Referring to the judgment of Lord Greene in the Court of Appeal in Associated Provincial Picture Houses v. Wednesbury Corporation [1948] 1 KB 223, Lord Diplock in Council of Civil Service Unions and Others v. Minister for the Civil Service (the 'GCHQ' case) [1985] AC 374 said that irrationality could now be succinctly referred to as "Wednesbury unreasonableness" (p.410). Thus in this article the terms irrationality and Wednesbury unreasonableness are used interchangeably to denote the same ground of review.

${ }^{9}$ In the 'GCHQ' case Lord Diplock described an irrational decision as a decision which was (ibid., p.410): "So outrageous in its defiance of logic and accepted moral standards that no sensible person who had applied his mind to the question to be decided could have arrived at it." The author therefore questioned whether the facts in several unreasonableness cases were irrational according to the standard implied by this definition.

${ }^{10}$ The judicial review of administrative powers is often justified on the basis that it is enforcing the will of Parliament expressed through an enabling statute - see, for example, Oliver (1986). However, other commentators such as Sir John Laws have described this enforcement of legislative will argument as a "fig leaf"- see Laws (1995).

${ }^{11}$ See Harlow and Rawlings (1984, pp.42-47).

${ }^{12}$ See, for example, Griffith (1979), (1985), (1997) and (2000). Adam Tomkins is perhaps Griffith's new standard bearer - see, for example, Tomkins (2002), (2003), (2004), (2005a) and (2005b). For criticisms of political constitutionalism, see, for example, Poole (2005) and (2007). A recent partial defence of political constitutionalism is Gee (2008).

${ }^{13}$ See, for example, McAuslan (1971) and (1983) and McAuslan and McEldowney (1985).
} 
about the courts holding the state ever more to account at the expense of political scrutiny - the author is naturally inclined to view his earlier finding about the judicial review of the merits of administrative action as something sinister. Perhaps a usurpation by the unelected judiciary of the power of the executive? Or is it something more benign? A matter of evolution, a natural repositioning of the courts within the normal jockeying for power that exists amongst the institutions of the state? Or is it something more systematic? A legitimate shift in the balance of power between the courts and government? The purpose of this article is to address some of these questions.

The author therefore intends to reassess here the classic limits of judicial review, reflecting the possible constitutional elevation of the courts which he found in the previous article. He proposes to do this by examining the possible motives for judicial intervention in some of these merits-review cases from the earlier piece with a view to questioning whether the low standards of irrationality employed were in fact within constitutional norms. To this end, much of this article considers the legitimacy of the manner in which the courts conducted merits-review. That is, the author questions whether some of the judges in these earlier cases actually employed a different test of review to irrationality - proportionality, for example - which may affect the conclusion one draws about their constitutionality. The remainder of this article considers the legitimacy of some of these merits-review cases by reference to the context of the administrative decision under examination; this is with particular reference to the HRA which has now made the applicability of irrationality to rights' cases possibly redundant. ${ }^{14}$ For reasons of space the author is unable to complete an evaluation of the HRA's impact on the constitutionality of employing low standards of irrationality so is forced to leave some discussion of this issue for a later article. Suffice it to say, however, this does not prevent him from drawing some important, preliminary conclusions here that the cases of merits-review identified in the previous piece were arguably legitimate.

\section{The Judicial Review of Merits}

\footnotetext{
${ }^{14}$ See Hilson (2003, p.142).
} 
In the first article, it was stated above, the author examined several cases where the courts ruled that the administrative decision-makers in question had acted contrary to the principle of Wednesbury unreasonableness/irrationality, questioning whether the case facts justified the judges in holding the decisions to be unlawful. ${ }^{15}$ If not, this had caused the courts to review the merits of the executive activity under consideration. For the purposes of this article it will be necessary to revisit the low standards of irrationality employed by the courts in two of these cases: Regina v. Coventry City Council, Ex parte Phoenix Aviation ${ }^{16}$ and Regina v. Cambridge District Health Authority, Ex parte $B^{17}$ in the Divisional Court.

In Ex parte Phoenix Aviation Simon Brown LJ (as he then was) held that Coventry City Council had acted unlawfully in restricting the flights of live animals from Coventry Airport, after breaches of airport security by public demonstrators opposed to the exports. The judge said: “The council’s resolution was wholly disproportionate to the security risk presented at the time.”18

Here, Mr Brewer, the Assistant Chief Constable of Warwickshire Police, was worried about the penetration of the airport's perimeter fence by demonstrators so wrote to the airport manager, expressing his concerns should the flights resume. He urged the manager to undertake a comprehensive review of security (since the police did not have a responsibility to protect the airport from trespass). In following the police's advice, the airport authorities and the council explored the option of improving the strength of the airport's perimeter fence. Because of the likely time to complete the work (2-3 months), and its estimated cost (£400,000), the next best course of action to prevent the incursion by the demonstrators, it seems to the author, was to cease the live animal exports. Is it right, therefore, to categorise this eventual decision by the airport authorities and the council as irrational in a public law sense? Was this not a

\footnotetext{
${ }^{15}$ Turner (2006).

${ }^{16}$ [1995] 3 All ER 37.

${ }^{17}$ [1995] 1 FLR 1055. The author also analysed the rulings of the House of Lords in Wheeler and Others v. Leicester City Council [1985] AC 1054, the Court of Appeal in West Glamorgan County Council v. Rafferty and Others [1987] 1 WLR 457, the Court of Appeal in Regina v. Secretary of State for Trade and Industry, Ex parte Lonrho PLC The Times, 18 January 1989 and the Court of Appeal in Regina v. Cornwall County Council, Ex parte Cornwall and Isles of Scilly Guardians Ad Litem and Reporting Panel [1992] 1 WLR 427.

${ }^{18}$ [1995] 3 All ER 37, p.63.
} 
reasonable option addressing the unease which the police had expressed? If so, it is contended that this was an engagement by Simon Brown LJ in the merits of the council's decision as the judge adopted a low standard of irrationality.

In Ex parte $B$ the decision of the Cambridge District Health Authority not to fund further medical treatment for a girl, B, aged ten with cancer was under scrutiny, Laws J (as he then was) ruling this was irrational. Again, was this an administrative decision that was unlawful in a public law sense? The author argues that it was not. First, the cancer treatment the applicant required had a success rate of only between 10 and 20\%, it was at variance with the majority of medical opinion and was experimental rather than standard therapy. Secondly, arguably, the judge attached too little weight to the opinions of the doctors who had treated the girl for much of her life: they did not believe in subjecting her to further suffering and trauma when the prospects of success were so slight, and carried a high risk of early morbidity. Thirdly, B had already undergone a course of total body irradiation which, according to accepted medical opinion, was therapy which no one should undergo more than once. Finally, substantial expenditure on treatment with such a small prospect of success was not an effective use of financial resources. With a limited budget, the authority, it is fair to say, had a responsibility to ensure that sufficient funds were available for the care of other patients. ${ }^{19}$

Ex parte Phoenix Aviation and Ex parte $B$ are just two examples taken from a larger sample of merits-review cases identified by the author in the first article of this study. But were these low standards of intervention in fact illegitimate? The purpose of this article is to address this question.

\section{The Manner of Merits-Review}

In examining the constitutionality of the low standards of irrationality identified in the previous article, the author here considers the legitimacy of the manner in which the courts maybe conducted merits-review. That is, did the judges in these earlier cases actually adopt a different test of review to irrationality? If so, what effect does this have

\footnotetext{
${ }^{19}$ The ruling of Laws J was reversed by the Court of Appeal: Regina v. Cambridge District Health Authority, Ex parte B [1995] 1 WLR 898.
} 
on the legitimacy of the low standards employed, if at all? The possible application of the proportionality test instead of the irrationality test is assessed first.

i) The application of proportionality

It will be recalled that Simon Brown LJ in Ex parte Phoenix Aviation said: "The council's resolution was wholly disproportionate to the security risk presented at the time."20 These words suggest that the judge may have reviewed the merits of the Coventry City Council's decision because he was employing a different test of review to irrationality, the proportionality principle. ${ }^{21}$

Because of the potential for a review of merits by the courts, Lord Lowry in the House of Lords in Regina v. Secretary of State for the Home Department, Ex parte Brind ${ }^{22}$ delivered a strong rejection of the proportionality test. This was based primarily on the constitutional principle of the separation of powers. ${ }^{23}$ The other judges, Lords Bridge, Ackner, Templeman and Roskill, were less dismissive, though they were certainly hesitant about recognising the principle as a stand alone head of judicial review. For example, Lord Roskill said:

"[The adoption of proportionality] in the present case would be for the court to substitute its own judgment of what was needed to achieve a particular objective for the judgment of the Secretary of State upon whom that duty has been laid by Parliament. But so to hold in the present case is not to exclude the possible future development of the law in this respect.”24

\footnotetext{
${ }^{20}$ [1995] 3 All ER 37, p.63.

${ }^{21}$ See Fordham (1997, p.505).

22 [1991] 1 AC 696.

${ }^{23}$ Ibid., pp.766-767. The judge justified his opinion for several reasons: first, most executive decision-makers were elected, for judges to make administrative decisions in place of them would be an abuse of their supervisory jurisdiction; secondly, judges were generally illequipped by training or experience to decide an answer where the scales were evenly balanced; and, thirdly, the likely increase in applications for judicial review if the standard of review were lowered.

${ }^{24}$ Ibid., p.750. Although the House of Lords was loath to recognise the proportionality test as an independent ground of judicial review, this did not have the effect of limiting its application. The court accepted that it could be of relevance in establishing irrationality - see later discussions of the proportionality test in the main text of this article.
} 
English lawyers have experience of the proportionality test through acquaintance with the jurisprudence of the European Union $^{25}$ and constitutional appeals to the Privy Council. ${ }^{26}$ The principle is also applied by the European Court of Human Rights (ECtHR) where a "qualified right" of the ECHR is under consideration. ${ }^{27}$ Assuming a state has lawful authority for its actions, it can infringe basic rights for a legitimate aim, like national security or the prevention of disorder or crime, where such an infringement is necessary in a democratic society.

A popular explanation of proportionality review was given by Lord Clyde in the Privy Council in de Freitas v. Permanent Secretary of Ministry of Agriculture, Fisheries, Lands and Housing. ${ }^{28}$ In determining whether a limitation was arbitrary or excessive the judge said a reviewing court should ask itself:

"[W]hether: (i) the legislative objective is sufficiently important to justify limiting a fundamental right; (ii) the measures designed to meet the legislative objective are rationally connected to it; and (iii) the means used to impair the right or freedom are no more than is necessary to accomplish the objective."29

The proportionality principle therefore possesses a "principled template of relevant questions". ${ }^{30}$ That is, once a reviewing court has been convinced by the legitimacy of the aim identified by the state, such as national security or the protection of the rights and freedoms of others, and there was a reasonable nexus between the means to achieve the aim - the infringement of the right - and the aim itself, it must then consider whether there was a pressing social need for infringing the right. In asking itself the latter question the reviewing court is determining whether the means are proportionate to the aim being pursued. ${ }^{31}$

\footnotetext{
${ }^{25}$ Article 5(3) of the EC Treaty states: "Any action by the Community shall not go beyond what is necessary to achieve the objectives of this Treaty."

${ }^{26}$ See, for example, Thomas v. Baptiste [2000] 2 AC 1.

${ }^{27}$ Qualified rights are generally recognised as Articles 8-11 of the ECHR but can be applied to other Articles - see footnote 83.

${ }^{28}$ [1999] 1 AC 69.

${ }^{29}$ Ibid., p.80.

${ }^{30}$ See Fordham (2002, p.110).

${ }^{31}$ In $R$ (Abdi and Nadarajah) v. Secreatary of State for the Home Department [2005] EWCA

Civ 1363 Laws LJ extended the scope of the proportionality test to cases concerning

legitimate expectations - the area of administrative law which obliges executive decision-
} 
Some implications for reviewing courts when employing the proportionality test were identified by Lord Steyn in Regina (Daly) v. Secretary of State for the Home Department $^{32}$ (when contrasting the difference in this principle's application with the Wednesbury irrationality test). The judge said, first, proportionality may require the reviewing court to assess the balance which the decision maker has struck, not merely whether it was within the range of rational or reasonable decisions. Secondly, it may go further than the irrationality test inasmuch as it may require attention to be directed to the relative weight accorded to interests and considerations. ${ }^{33}$

Proportionality therefore requires the courts to compare the weight attached to the right which has been infringed - the private right of the applicant - with the weight attached to the competing justification for infringing that right - the public interest. Judges could not conceivably employ such a process of review without being involved in some adjudication of the merits of the infringement. ${ }^{34}$ The proportionality test is clearly a searching method of review and projects courts more into the role of the primary decision-maker than the irrationality test, which simply requires the decision maker to remain within an area of reasonable responses. ${ }^{35}$ However, this has not prevented several academic commentators, such as Craig, ${ }^{36}$ Jowell, ${ }^{37}$ Lester, ${ }^{38}$ Wong, ${ }^{39}$ Elliott, ${ }^{40}$

makers to honour assurances or past practices. In so doing, he made no distinction between proportionality's applicability to substantive as well as procedural legitimate expectations. Although welcoming this articulation of the legitimate expectation principles, Elliott questions whether proportionality is the appropriate tool for doing so in all legitimate expectation cases - see, Elliott (2006a) and (2006b). For a critical response to Elliott, see, for example, Knight (2007).

32 [2001] 2 AC 532.

${ }^{33}$ Ibid., p.547.

${ }^{34}$ An argument that applying the proportionality test means that the courts always conduct review upon the merits is strictly incorrect: judges also adopt high standards when employing this principle - see later discussions in main text.

${ }^{35}$ For a useful explanation of how proportionality can differ from irrationality in practice see, for example, Taggert (2004). This revisits the original Wednesbury case in the light of the enactment of the HRA and the adoption of the proportionality test to infringements of Article 8 , the right to respect for one's private and family life, home and correspondence, and Article 10 , the right to freedom of expression, of the ECHR. These would be the convention rights at issue if the same case facts - prohibiting children under the age of 15 from attending cinemas on a Sunday with or without an adult - were to arise again in the post HRA era.

${ }^{36}$ Craig (1997), (1998) and (1999). 
Fordham ${ }^{41}$ and Hickman, ${ }^{42}$ from arguing (or implying) that the proportionality test should not be confined to EU and ECHR Law. For example, Fordham seems unrestrained in this regard: “There [is]... an irresistible case for recognising proportionality as a self-standing domestic law principle of administrative law, both in fundamental rights cases and more generally." 43 In the face of strong academic support, therefore, the reviews of merits identified in the previous article of this study such as $E x$ parte Phoenix Aviation and Ex parte B may have been legitimate where the label of the irrationality test disguised the adoption of the proportionality test.

Fordham et al are not the only proponents of proportionality. There have been those acting in a judicial capacity who have (at the very least) implicitly endorsed the use of the test more widely in domestic judicial review. In the House of Lords in Brind a majority of the judges, as stated above, hesitated, if not rejected, the wider application of proportionality. Indeed, de Burca has argued that Lord Templeman employed the proportionality test there in arriving at his ruling. ${ }^{44}$

More recently, in Regina (Alconbury Developments Ltd) v. Secretary of State for the Environment, Transport and the Regions ${ }^{45}$ the House of Lords were again invited to consider the more general employment of proportionality in domestic law. In the case of Lord Slynn, for example, he plainly envisaged proportionality becoming an independent head of judicial review: ${ }^{46}$

\footnotetext{
${ }^{37}$ Jowell (1996) and (2000) and Jowell and Lester (1987) and (1988).

${ }^{38}$ Ibid (1987) and (1988) and Lester (2001a). Lord Lester gives a useful explanation of the adoption of the proportionality test in other jurisdictions in Lester (2001b).

${ }^{39}$ Wong (2000).

${ }^{40}$ Elliott (2001).

${ }^{41}$ Fordham (2002).

${ }^{42}$ Hickman (2007).

${ }^{43}$ Fordham (2002, p.110).

${ }^{44}$ De Burca (1997, p.574).

45 [2003] 2 AC 295.

${ }^{46}$ On this point Lord Slynn was, arguably, in a minority. Lord Nolan, for example, indicated there was no need to extend the grounds of review which he regarded as broad and generous (ibid., para 62). Lord Clyde said that it might well be difficult to achieve a sufficient enlargement to meet the stated purpose without jeopardising the constitutional balance between the role of the courts and the role of the executive (ibid., para 169). The issue was not mentioned by either Lord Hoffman or Lord Hutton.
} 
"I consider...the time has now come to recognize that this principle is part of the English administrative law, not only when judges are dealing with Community acts but also when they are dealing with acts subject to domestic law. Trying to keep the Wednesbury [irrationality] principle and proportionality in separate compartments seems to me to be unnecessary and confusing." 47

The House of Lords seemingly embraced the wider adoption of proportionality in Regina (Daly) v. Secretary of State for the Home Department. ${ }^{48}$ Here the court was examining the legality of the blanket policy of the Secretary of State in requiring a prisoner's absence during cell searches whenever privileged legal correspondence held by him/her was examined but not read. The court ruled that this practice was unlawful since, inter alia, such an action might affect a prisoner's willingness to communicate freely with his/her legal adviser. Lord Bingham said, in words reminiscent of the proportionality test in ECHR cases: “The infringement of prisoners' rights to maintain the confidentiality of their privileged legal correspondence is greater than is shown to be necessary to serve the legitimate public objectives already identified." 49

Furthermore, in implicitly supporting a greater acceptance of the proportionality test, Lord Cooke in Daly appeared to do so at the expense of the irrationality test:

"[I] think that the day will come when it will be more widely recognised that [Wednesbury irrationality] was an unfortunately retrogressive decision in English administrative law... It may well be, however, that the law can never be satisfied in any administrative field merely by a finding that the decision under review is not capricious or absurd."

Following judicial statements of members of the House of Lords in Alconbury and Daly Craig argues that the House of Lords had given strong, but not conclusive,

\footnotetext{
${ }^{47}$ Ibid., para 51.

48 [2001] 2 AC 532.

${ }^{49}$ Ibid., p.544.

${ }^{50}$ Ibid., p.549.
} 
support to the emergence of proportionality as a separate ground of judicial review. ${ }^{51}$ One of the more recent authoritative judicial discussions of this issue was the ruling of the Court of Appeal in Regina (British Civilian Internees Far East Region) v. Secretary of State for Defence, ${ }^{52}$ where Dyson LJ contributed further to the courts' acceptance of the proportionality principle. Here the applicants wished to challenge the compensation scheme for British citizens interned in Japan during World War II. The judge said there was a strong case for recognising proportionality as part of English domestic law which did not involve Community law or human rights. ${ }^{53}$

This section has begun to assess the constitutionality of some of the merits-review cases the author identified in the previous article of this study. In particular, although the cases were examples where the courts seemingly employed the irrationality test, they were arguably ones in which a form or variation of proportionality review was exercised. Many academic and judicial commentators support the more general adoption of the proportionality test in conventional judicial review. Whether the principle ought to replace the irrationality test or be an addition to it is largely irrelevant to the purpose of this article. What is relevant, however, is establishing the legitimacy of these merits-review cases found previously. The author here has identified the ruling of Simon Brown LJ in Ex parte Phoenix Aviation as an example where proportionality was maybe employed in all but name. This section therefore concludes that this review of merits was arguably constitutionally justified because of the nature of review exercised. The next section of this article continues the theme of this one: it considers the legitimacy of these merits-review cases where the manner in employing low standards of irrationality was the possible adoption of another method of judicial review, the "hard look" test.

\footnotetext{
${ }^{51}$ See Craig (2001, p.592). Elliott is more enthusiastic (2002, p.98): “[As regards Daly] Lord Diplock's prediction in $G C H Q$ that proportionality may one day be recognised as an independent principle of domestic judicial review has come to pass.”

52 [2003] QB 1397.

${ }^{53}$ Ibid., p.1413. However, Dyson LJ did say it was not for the Court of Appeal to perform the Wednesbury irrationality "burial rites". The continuing existence of the Wednesbury test had been acknowledged by the House of Lords on more than one occasion (pp.1413-1414). The appeal in British Civilian Internees Far East Region was rejected by the House of Lords so arguably the higher court did not feel the need to 'terminate' irrationality altogether. Because of this, Fordham notes (Fordham 2007, p.267): "The Law Lords, failing to take the hint, put the development of the common law back a decade.” He does predict that common law proportionality will eventually become a free standing head of challenge, notwithstanding the House of Lords rejecting the appeal - see Fordham (2008, p.67).
} 
ii) The application of "hard look"

It was submitted above, and in the first article of this study, that the Divisional Court in Ex parte B may have adopted a low standard of unreasonableness. This is possible if Laws J was employing, as James and Longley have argued, ${ }^{54}$ a different approach to traditional judicial review - one based upon the "hard look" review of administrative activity in the United States.

In reference to the ruling of the United States Supreme Court in Motor Vehicle Manufacturers Association v. State Farm Mutual Automobile Insurance Company, ${ }^{55}$ Craig gives an explanation of the "hard look" test of challenge. He says:

"[The Court said] it could intervene if any of the following defects were present: if the agency relied on factors which Congress had not intended it to consider; failed to consider an important aspect of the problem; offered an explanation which ran counter to the evidence before the agency; was so implausible that it could not be sustained; or failed to provide a record which substantiated its findings...The "hard look" doctrine therefore represents a shift from a previously more minimal standard of review [in the US], where judicial intervention would occur only if there was irrationality..."56

In essence, the objective with this test is to ensure that policy alternatives are adequately considered, that reasons are proffered for agency decisions, and that differing interests can present their views to the agency and have those views adequately discussed. ${ }^{57}$ "Hard look" therefore engages a court more in reviewing the manner in which an administrative decision was reached. For example, it not only decides matters that are relevant to the exercise of a discretion, but also the weight to be attached to them. This is clearly not the same as the UK courts' application of the Wednesbury principle: irrationality review is concerned only with the outcome of an administrative decision and

\footnotetext{
${ }^{54}$ James and Longley (1995, p.371).

55463 US 29 (1983).

${ }^{56}$ Craig (1994, p.438).

${ }^{57}$ Ibid., p.439.
} 
whether it was outrageous in its defiance of logic. Indeed, the judicial consideration of the weight to be attached to relevant matters was excluded from irrationality by the House of Lords in Tesco Stores v. Secretary of State for the Environment. ${ }^{58}$

Despite "hard look" obviously being a more intensive form of review than irrationality, this has not prevented Sir Stephen Sedley (extra-judicially), ${ }^{59}$ Harden and Lewis ${ }^{60}$ and James and Longley ${ }^{61}$ from arguing (or implying) that it is legitimate for the courts to apply it when exercising their powers of judicial review. For example, Harden and Lewis state: "The soft standard of judicial review associated in Britain with the Wednesbury test is inadequate...The hard look doctrine is justified as the most acceptable guarantee that all values are genuinely considered during the policy-making process.”62

Hence, Laws J's employment of low standard of irrationality in Ex Parte B was maybe legitimate, if, in fact, the judge was applying the "hard look" test. The next section continues the theme of this article in assessing the legitimacy of the reviews of merits identified previously, albeit analysing the effect the context of the administrative decision at issue - a breach of the applicant's fundamental rights, for example - had on the low standard of irrationality arguably adopted.

\section{The Context of the Administrative Decision}

i) Infringements of fundamental rights

In addition to the manners in which Laws $\mathrm{J}$ and Simon Brown LJ may have engaged in a review of merits, the context of the administrative decisions under consideration is potentially another important issue in the debate about their constitutionality. For example, in Ex parte $B$ the fact that fundamental rights were engaged possibly affected the standard of judicial intervention. Laws J said: "The law requires that where a public

\footnotetext{
${ }^{58}$ [1995] 1 WLR 759. Of course, if "hard look" constitutes an assessment of the weight to be attached to relevant matters, then this is similar to the methodology of proportionality review identified in the speech of Lord Steyn in Regina (Daly) v. Secretary of State for the Home Department [2001] 2 AC 532 (para 28).

${ }^{59}$ Sedley (1997, p.9).

${ }^{60}$ Harden and Lewis (1986, p.205).

61 James and Longley (1995, pp.372-373).

${ }^{62}$ Harden and Lewis (1986, pp.272-275).
} 
body enjoys a discretion whose exercise may infringe [a basic liberty], it is not to be permitted to perpetrate any such infringement unless it can show a substantial objective justification on public interest grounds.”63 This test of irrationality employed by Laws J, in requiring the state to identify a legitimate aim for its decision to cease cancer therapy for a terminally ill child, and to give very good reasons for doing so, arguably explains the low standard he adopted.

Simon Brown LJ may also have conducted a review upon the merits in Ex parte Phoenix Aviation because of the context of the administrative decision. The judge said:

“Tempting though it may sometimes be for public authorities to yield too readily to threats of disruption, they must expect the courts to review any such decision with particular rigour - this is not an area where they can be permitted a wide measure of discretion. As when fundamental human rights are in play, the courts will adopt a more interventionist role.”64

Simon Brown LJ therefore believed that engaging in a review of merits was justified where the court's purpose was to uphold the rule of law and prevent lawful trade from being disrupted because of public protest. Nevertheless, how widespread is this view that adopting a low standard of irrationality is legitimate if administrative action, for example, has breached fundamental rights? For example, Allan argues:

"The virtue of judicial restraint must depend on the nature of the [infringement] alleged. The distinction between appeal and review must be an elastic one, permitting more intensive scrutiny of executive action which threatens basic liberties than might be appropriate in other cases.”65

Where fundamental rights have been engaged, the courts have developed an "anxious scrutiny" approach to irrationality. ${ }^{66}$ For example, in the House of Lords in Brind the

\footnotetext{
${ }^{63}$ [1995] 1 FLR 1055, p.1060.

${ }^{64}$ [1995] 3 All ER 37, p.62.

${ }^{65}$ Allan (1993, p.188). Allan does advocate a wider review of merits by the courts - see Allan (1998).

${ }^{66}$ This was developed first by the House of Lords in $R \mathrm{v}$. Secretary of State for the Home Department, Ex parte Bugdaycay [1987] AC 514. There Lord Bridge said (p.531): "When an
} 
court held that the Secretary of State had not acted unreasonably in preventing the direct speech of suspected terrorists (voice-overs by actors were used). However, the Minster's infringement of the right to freedom of expression clearly affected the test of irrationality the court employed. Lord Bridge said:

"In deciding whether the Secretary of State...could reasonably impose the restriction he has imposed on the broadcasting organisations, we are...perfectly entitled to start from the premise that any restriction of the right to freedom of expression requires to be justified and that nothing less than an important competing public interest would be sufficient to justify it." 67

By requiring the Secretary of State to justify his decision on the basis of an important competing public interest, Lord Bridge was obliging the Minister to show not only that the infringement had lawful grounds, but that it needed to be balanced against a legitimate objective of the state. Is this not proportionality, or at least a variation of it? If so, the judge was seemingly lowering the standard of the irrationality test in rights' cases by waiving the less onerous obligation of the applicants to prove that the infringement was not within a range of options open to a reasonable decision maker. ${ }^{68}$

If Lord Bridge was not formally adopting proportionality in rights' cases, then there is every reason to believe Lord Templeman did so since his speech was couched in a language suggestive of this test: "[T]he interference with freedom of expression must be necessary and proportionate to the damage which the restriction is designed to prevent."

Because of inconsistent judgments by the House of Lords ${ }^{70}$ the standard of irrationality adopted in this case was arguably unclear. In this regard the ruling of the Court of

administrative decision...is said to be one which may put the applicant's life at risk, the basis of the decision must surely call for the most anxious scrutiny.”

${ }^{67}$ [1991] 1 AC 696, pp.748-749.

${ }^{68}$ Hunt agrees - see Hunt (1997, p.183).

${ }^{69}$ [1991] 1 AC 696, p.751. De Burca agrees that Lord Templeman adopted the proportionality test - see de Burca (1997, p.574).

${ }^{70}$ Lord Roskill concurred with the speech of Lord Bridge, Lord Lowry concurred with the speech of Lord Ackner and Lords Bridge, Ackner and Templeman did not concur with any of their fellow judges. 
Appeal in Regina v. Ministry of Defence, Ex parte Smith ${ }^{71}$ is a useful guide to determining the legitimacy of merits-review cases where fundamental rights have been infringed. In Smith Sir Thomas Bingham MR (as he then was) accepted the submission of counsel for one of the appellants, Mr. Pannick QC, regarding the appropriate standard to be employed by the courts in this context:

\begin{abstract}
"The court may not interfere with the exercise of an administrative discretion on substantive grounds save where the court is satisfied that the decision is unreasonable in the sense that it is beyond the range of responses open to a reasonable decision-maker. But in judging whether the decision-maker has exceeded this margin of appreciation the human rights context is important. The more substantial the interference with human rights, the more the court will require by way of justification before it is satisfied that the decision is reasonable."72
\end{abstract}

This dictum is possibly a distillation of the principles outlined above in the speech of Lord Bridge in Brind. However, since the judge here said not only must there be a justification for infringing a fundamental right, but the more serious the infringement, the more convincing must be the justification, some commentators have argued that this approach is more akin to a proportionality type of test than Brind. ${ }^{73}$ For example, Elliott argues:

"This form of review...presents a much less opaque methodology than that which is usually associated with Wednesbury [irrationality]...Indeed the structure of the English courts' inquiry in Smith - given the recognition of a valued norm and of the need for its infraction to be justified by reference to a competing legitimate aim - bears substantial resemblance to the methodology of proportionality review." 74

\footnotetext{
${ }^{71}$ [1996] QB 517.

72 Ibid., p.554.

${ }^{73}$ Some writers hold an opposite view - see, for example, Hickman (2004, p.186). If the Court of Appeal in Smith did in fact apply proportionality, it was a higher standard than that adopted by the European Court of Human Rights in its 'appeal'. See Smith and Grady v. United Kingdom (1999) 29 EHRR 493 (p.543).

${ }^{74}$ Elliott (2002, p.106).
} 
Some five years after Smith, in Regina v. Lord Saville of Newdigate, Ex parte $A,{ }^{75}$ Lord Woolf MR (as he then was) again stressed the applicability of basic liberties to the irrationality test. In ruling that the decision of the Bloody Sunday Inquiry chaired by Lord Saville not to grant anonymity to British soldiers giving evidence was unreasonable, the judge said:

"What is important to note is that when a fundamental right such as the right to life is engaged, the options available to the reasonable decision-maker are curtailed. They are curtailed because it is unreasonable to reach a decision which contravenes or could contravene human rights unless there are sufficiently significant countervailing considerations. In other words, it is not open to the decision-maker to risk interfering with fundamental rights in the absence of compelling justification. Even the broadest discretion is constrained by the need for there to be countervailing circumstances justifying interference with human rights. The courts will anxiously scrutinize the strength of the countervailing circumstances and the degree of interference with the human rights involved and then apply the test accepted...in Smith."76

The standard of judicial intervention adopted by the Court of Appeal here was clearly low, reflecting the threats to the safety of the service personnel that publication of their identities would pose - but at what level? Hilson has argued that the test employed in Saville is, in fact, a more intensive method of review than that employed by the Court of Appeal in Smith: ${ }^{77}$

"In Saville, the court not only adjusted the Smith test...but also lowered the threshold of its application...The question is whether, if the Wednesbury principle is reinterpreted and applied in such a radical way, it remains the same principle or whether it has become proportionality in all but name."78

\footnotetext{
75 [2000] 1 WLR 1855.

${ }^{76}$ Ibid., p.1866.

${ }^{77}$ Hilson (2003).

${ }^{78}$ Ibid., p.134.
} 
Several judicial approaches to the irrationality test in rights' cases have been advanced. Despite difficulties in identifying precisely the standard employed in these cases, the judges clearly examined the administrative decisions at issue with some degree of intensity. To this end, a low threshold of intervention in the merits-review cases discussed earlier - Ex Parte B and Ex Parte Phoenix Aviation - was academically and judicially legitimate. Nevertheless, how is this interim conclusion about the justifiability of merits-review in rights' cases affected by the enactment of the Human Rights Act 1998 (HRA) in October 2000? This is the purpose of the next section.

ii) Breaches of the Human Rights Act 1998 (HRA) and the European Convention on Human Rights (ECHR)

Determining the degree of irrationality review where there have been infringements of basic liberties, and their legitimacy, may be academic since the coming into force in October 2000 of the Human Rights Act 1998 (HRA), ${ }^{79}$ allowing individuals to enforce Convention rights in domestic courts. ${ }^{80}$ The HRA incorporated some of the Articles of the ECHR ${ }^{81}$ into domestic law principally through s.3: "So far as it is possible to do so, primary legislation and subordinate legislation must be read and given effect in a way which is compatible with the Convention rights.” In interpreting primary and secondary legislation, the courts, according to s.2, must take into account the case law of the European Court of Human Rights (ECtHR). If a court cannot interpret a statute "so far as it is possible to do so", s.4(2) provides: "If the court is satisfied that the provision is incompatible with a Convention right, it may make a declaration of incompatibility.” A declaration of incompatibility is not an order invalidating an Act of Parliament on the basis that it infringes a Convention right. Amending offending primary legislation to make it Convention compatible is the preserve of the executive

\footnotetext{
${ }^{79}$ Procedurally, there are different rules for conventional judicial review and judicial review under the HRA. This means that, notwithstanding the coming into force of the HRA, infringements of fundamental rights may still have to be pursued through the traditional Wednesbury irrationality test. See, for example, Miles (2000) and Squires (2000).

${ }^{80}$ The HRA has come in for much criticism, most notably for 'inhibiting' the state's ability to fight terrorism - see, for example, Morton (2006), and more generally Dennis (2006) and Clayton (2007). However, the Parliamentary Joint Committee on Human Rights (JCHR) has recently recommended a Bill of Rights for the UK. In its opinion, the ECHR rights incorporated into UK law by the HRA do not go far enough in protecting the rights of, for example, vulnerable groups in society such as children - see JCHR (2008).

${ }^{81}$ See footnote 6 for a description of the Articles of the ECHR incorporated into UK law.
} 
through a fast track procedure under s.10 ${ }^{82}$ However the judicial review of secondary legislation is not excluded. Section 6(1) states: "It is unlawful for a public authority to act in a way which is incompatible with a Convention right.”

The intensity of review and qualified Convention rights

In determining breaches of the ECHR the ECtHR applies the proportionality test to “qualified rights”. These include Articles 8-11 which require a balancing of competing private interests - privacy, freedom of conscience, thought and religion, freedom of expression and freedom of association and assembly - and public ones - national security, public safety and the economic well being of the country, for example. The test has a role to play in considering breaches of other Articles of the $\mathrm{ECHR}^{83}$ but is excluded from reviews of Articles $3,^{84} 4(1), 6,7(1)$ and 12, which have no limitations, and Articles $2^{85}$ and 5 where the limitations are specific.

\footnotetext{
${ }^{82}$ In fact practice has shown that the executive is more likely to address the incompatibility of legislation by replacing it with an Act that is compatible rather than invoking this "Henry VIII” clause under s.10.

${ }^{83}$ The proportionality test can be applied to other Articles of the ECHR such as Article 15. This allows a state to derogate from certain Articles of the ECHR in times of war or public emergency threatening the life of the nation. But this is only to the extent strictly required by the exigencies of the situation. (Note: in a domestic context, as Article 15 is not a Convention right according to the HRA s.1, a derogation is not lawful unless designated by the HRA
} s.14.)

${ }^{84}$ Article 3 of the ECHR, the prohibition on torture, says: "No one shall be subjected to torture or to inhuman or degrading treatment or punishment." Note: although there are positive obligations imposed on states to prevent ill-treatment in Article 3 (see, for example, E v. United Kingdom (2003) 36 EHRR 31), these must not impose disproportionate burdens on state authorities (see, for example, Osman v. United Kingdom (2000) 29 EHRR 245). This is an example, therefore, where proportionality does have some part to play in assessing breaches of Article 3 - see Hickman (2004).

${ }^{85}$ Article 2 of the ECHR, the right to life, says: “(1) Everyone’s right to life shall be protected by law. No one shall be deprived of his life intentionally save in the execution of a sentence of a court following his conviction of a crime for which this penalty is provided by law. (2) Deprivation of life shall not be regarded as inflicted in contravention of this Article when it results from the use of force which is no more than absolutely necessary: (a) in defence of any person from unlawful violence; (b) in order to effect a lawful arrest or to prevent the escape of a person lawfully detained; (c) in action lawfully taken for the purpose of quelling a riot or insurrection.” However, in McCann v. United Kingdom (1995) 21 EHRR 97 the ECtHR said (para 149): “[The] the use of the term "absolutely necessary” in Article 2(2) indicates that a stricter and more compelling test of necessity must be employed from that normally applicable when determining whether State action is "necessary in a democratic society" under paragraph 2 of Articles 8 to 11 of the Convention. In particular, the force used must be strictly proportionate to the achievement of the aims set out in sub-paragraphs 2(a), (b) and (c) of Article 2.” This, therefore, recognises proportionality, albeit less intensively, in Article 2 of the ECHR. 
The case of Daly was referred to earlier in this article because of the House of Lords' general support for proportionality in domestic law. It is examined again here because the judges also required its application to breaches of qualified rights under the HRA. In Daly the court, it will be recalled, held that the blanket policy of the Secretary of State obliging prisoners to be absent during cell searches whenever their privileged legal correspondence was examined but not read - was unlawful. The court found, inter alia, that the policy amounted to a disproportionate interference with the applicant's right to respect for his correspondence under Article 8(1) of the ECHR. Lord Bingham said: “The infringement of prisoners’ rights to maintain the confidentiality of their privileged legal correspondence is greater than is shown to be necessary to serve the legitimate public objectives already identified."

The House of Lords has since applied the proportionality test to other qualified rights of the ECHR such as Articles 10(1) and 11(1) of the ECHR, the freedom of expression and the freedom of assembly and association respectively: Regina (Laporte) v. Chief Constable of Gloucestershire Constabulary. ${ }^{87}$ Here the police had stopped three coaches five kilometres away from an anti-Iraq war demonstration at RAF Fairford in Gloucestershire. The police believed that some passengers were likely to commit breaches of the peace so prevented all three of the coaches from continuing on to the demonstration. The police then escorted the coaches back to their place of origin, London. Lord Bingham said:

“There was no reason (other than [the applicant's] refusal to give her name, which however irritating to the police was entirely lawful) to view the claimant as other than a committed, peaceful demonstrator. It was wholly disproportionate to restrict her exercise of her rights under Article 10 and 11 because she was in the company of others some of whom might, at some time in the future, breach the peace." 88

\footnotetext{
${ }^{86}$ [2001] 2 AC 532, p.544.

${ }^{87}$ [2006] UKHL 55, [2007] 2 AC 105.

${ }^{88}$ Ibid., para 55. For examples of the House of Lords applying the proportionality test to qualified rights of the ECHR in other cases, see Regina (Williamson) v. Secretary of State for Education and Employment [2005] UKHL 15, [2005] 2 AC 246; Belfast City Council v. Miss Behavin' Limited [2007] UKHL 19, [2007] 1 WLR 1420 and Regina (Animal Defenders
} 
The UK courts now employ the proportionality principle since the coming into force of the HRA. Clearly, therefore, a review of merits is justified where infringements of qualified rights of the ECHR are alleged. In this regard, some of the reviews of merits identified in the first article in this study, but which have not yet been referred to fully in this article, such as Wheeler v. Leicester City Council ${ }^{89}$ and West Glamorgan County Council v. Rafferty, ${ }^{90}$ are arguably now legitimate in the light of the enactment of the HRA, if they were not so before October 2000. In Wheeler the council had proposed removing the use of a recreation ground from Leicester Rugby Club, for not having prevented some of its players from joining a rebel rugby tour to South Africa. In bringing pressure to bear on the club, with the ultimate threat of sanctions, was this not possibly a breach of the rebel rugby players’ ECHR rights under Article 9(1), the freedom of thought, conscience and religion, Article 10(1), the freedom of expression, and Article 11(1), the freedom of assembly and association? By attempting to prevent the players going to South Africa the council, it is submitted, were denying them a voice in opposing the world-wide ban on sporting links with that country. Perhaps the players had preferred the right to effect change to the then apartheid regime through active sports participation in the country? ${ }^{91}$ Assuming the players' fundamental rights under the ECHR had been engaged, proportionality would have obliged the council to justify a legitimate objective for the infringements and a proportionate balance to be undertaken between the public and private rights at issue.

A similar qualified right to that maybe engaged in Wheeler, Article 11(1), and other qualified rights of the ECHR, Article 8(1), the right to respect for private and family life, home and correspondence, and Article 1 of the $1^{\text {st }}$ Protocol, the protection of property, may have been infringed in Rafferty. Here West Glamorgan County

International) v. Secretary of State for Culture, Media and Sport [2008] UKHL 15, [2008] 2 WLR 781.

${ }^{89}$ [1985] AC 1054.

${ }^{90}$ [1987] 1 WLR 457.

${ }^{91}$ Indeed, Jowell and Lester (1988) suggest that Wheeler was a case where the proportionality test was maybe employed. They say (p.61): "Lord Templeman considered [the council's decision] to be a misuse of power, "punishing the club where it had done no wrong". Lord Roskill considered the withdrawal of a licence to be an unfair means of pursuing the council's ends. Both speeches reflect the notion of proportionality, Lord Templeman concentrating on the lack of relation between the penalty and the wrong, Lord Roskill concentrating on the lack of relation between the penalty and the council's legitimate objectives.” 
Council had acted irrationally in seeking an order for possession of land occupied by "gypsies”, who were causing a public nuisance, without providing them with alternative accommodation. Was this not, therefore, a prima facie denial by the council of the travellers' rights to respect for their home life, freedom of association and peaceful enjoyment of their possessions? If so, the court would have been obliged to balance these rights with the public interest of protecting disorder and crime, applying the proportionality test.

However, the adoption of the proportionality principle does not necessarily mean a reviewing court is engaging in a review of merits. For example, Maurice Kay LJ in the Court of Appeal in Regina (Clays Lane Housing Co-operative) v. Housing Corporation $^{92}$ reminded the courts that there is still a degree of latitude accorded to the executive when employing this test of review. He said that although proportionality required a balancing exercise, and a decision which was justified on the basis of a compelling case in the public interest, it did not require a decision that was the least intrusive of Convention rights. The "least intrusive" approach is a more intensive method of review than proportionality and adopted by courts in the US, for example. ${ }^{93}$ In this respect, some UK judges may not regard the proportionality test as obliging them to exercise the degree of enquiry that the author implied was maybe the case when he first discussed this principle in an earlier section of this article. What effect, therefore, does this possible inference about proportionality have on the conclusions drawn from the previous article in this study about irrationality review affording the courts the opportunity to review merits?

Furthermore, in the international sphere the ECtHR has adopted a "margin of appreciation" reflecting the social and cultural differences which exist amongst the member states of the Council of Europe, the signatories of the ECHR. This margin of appreciation is not necessarily evident in the various Articles of the ECHR under consideration but the context in which the Articles arise. To this end, the ECtHR can adopt high standards of proportionality, as was maybe the case in Handyside v.

\footnotetext{
92 [2004] EWCA Civ 1658, [2005] 1 WLR 2229.

${ }^{93}$ Ibid., para 25. This approach is adopted by, for example, the US Supreme Court in assessing legislative breaches of the Constitution - see the ruling of the US Supreme Court in Ashcroft v. American Civil Liberties Union 542 US 214 (2004).
} 
United Kingdom. ${ }^{94}$ Here the decision to prosecute the distributor of the Little Red Schoolbook under the Obscene Publications Act 1959 for the purpose of protecting public morals was lawful. Yes, the ECtHR applied the proportionality test - a suitable balance had been struck between the private right of the applicant to freedom of expression and the public interest of the state to protect the morals of children and young people - but it is submitted that it did not do so to any great degree. The court said:

"[It] is not possible to find in the domestic law of the various Contracting States a uniform European conception of morals. The view taken by their respective laws of the requirements of morals varies from time to time and from place to place, especially in our era which is characterised by a rapid and far-reaching evolution of opinions on the subject. By reason of their direct and continuous contact with the vital forces of their countries, State authorities are in principle in a better position than the international judge to give an opinion on the exact content of these requirements as well as on the "necessity" of a "restriction" or "penalty” intended to meet them...Consequently, Article 10(2) leaves to the Contracting States a margin of appreciation."95

Despite the margin of appreciation principle being applicable in a supra-national context there may be a similar principle - either "a discretionary area of judgment”, “a margin of discretion" or "judicial deference" - adopted by the UK courts when considering infringements of the ECHR in domestic law. ${ }^{96}$ In this regard, it is unlikely that the UK courts will examine breaches of qualified rights of the ECHR with any great intensity where a balance is to be struck between private and public considerations such as public morality, and, for example, the prevention of disorder and crime and national security. ${ }^{97}$ If so, the degree of review in these contexts

\footnotetext{
${ }^{94}$ (1976) 1 EHRR 737.

${ }^{95}$ Ibid., para 48. Similar high standards of proportionality can be detected in the case law of the European Court of Justice - see, for example, (Case C-331/88) Regina v. Minister for Agriculture, Fisheries and Food, Ex parte FEDESA [1990] ECR I-4023.

${ }^{96}$ An explanation as to why the term "margin of appreciation" is inappropriate to domestic HRA cases is given by Rivers - see Rivers (2006, p.175).

${ }^{97}$ See, for example, the speeches of Lord Hope in the House of Lords in Regina v. DPP, Ex parte Kebilene [2000] 2 AC 326, p.381 and Lord Bingham in Regina v. Secretary of State for the Environment, Transport and the Regions, Ex parte Spath Holme Ltd [2001] 2 AC 349,
} 
possibly results in an occasional overlap between the proportionality test and the Wednesbury irrationality one; that is, cases would be decided in the same way whichever approach is adopted. For example in the House of Lords in Brind, although the court was loath to recognise the proportionality test as an independent ground of judicial review (as stated in an earlier section), this did not have the effect of limiting its application. The court accepted that the principle could be of relevance in establishing irrationality. Lord Ackner said: "[Counsel] has contended that in issuing these directives the Secretary of State has used a sledgehammer to crack a nut. Of course that is a picturesque way of describing the Wednesbury irrational test."98 Similar opinions as to the potential overlap of the two tests were expressed in the House of Lords by Lords Slynn and Cooke in Regina v. Chief Constable of Sussex, Ex parte International Trader's Ferry Limited ${ }^{99}$ and Lord Steyn in Daly. ${ }^{100}$

In fact, are UK courts adopting a margin of appreciation when considering breaches of qualified rights under the HRA? The ruling of the House of Lords in Regina (ProLife Alliance) v. $B B C^{101}$ is possibly evidence that they are doing so. In the pre-HRA era the courts repeatedly stated that freedom of expression was a constitutional right. One example was Derbyshire County Council v. Times Newspapers ${ }^{102}$ where a national newspaper could not be sued for defamation by a local authority. However, there have been recent cases where the courts in domestic law have deferred to the executive in allowing infringements of this fundamental right on the grounds of taste and decency and the prevention of public disorder. As regards the former issue, public morals, in Pro-Life Alliance ${ }^{103}$ a decision by the BBC and the ITV companies to limit severely

p.395. Nevertheless, as regards national security, note, for example, the ruling of the House of Lords in Regina (A) v. Secretary of State for the Home Department [2004] UKHL 56, [2005] 2 AC 68 where the judges disagreed with the government's assessment of the existing terrorist threat to the security and safety of the UK. This is despite the context, national security, being an area where the courts traditionally defer to the opinions of the executive. The ruling of the House of Lords has received widespread academic praise. See, for example, Feldman (2005, p.273).

${ }^{98}$ [1991] 1 AC 696, p.759.

${ }^{99}$ [1999] 2 AC 418, pp.439 and 452.

100 [2001] 2 AC 532, p.548.

101 [2003] UKHL 23, [2004] 1 AC 185.

102 [1993] AC 534. Lord Keith said (p.547): "It is of the highest public importance that a democratically elected governmental body, or indeed any governmental body, should be open to uninhibited public criticism. The threat of a civil action for defamation must inevitably have an inhibiting effect on freedom of speech.”

103 [2003] UKHL 23, [2004] 1 AC 185. 
the claimants' transmission of its election broadcast was not unlawful. Although the claimants were prepared to permit the screening depicting a suction abortion after $10.00 \mathrm{pm}$, with a warning about its content prior to transmission, the House of Lords showed due deference to the broadcasting authorities in determining that, even with this compromise, it was indecent and in bad taste. ${ }^{104}$

In Regina (Farrakhan) v. Secretary of State for the Home Department ${ }^{105}$ the claimant, the leader of the Nation of Islam, was refused entry into the UK on the basis that he would incite racial hatred and be likely to commit other public order offences. Although the Court of Appeal found that Article 10(1) was engaged, it accepted the decision to exclude the claimant from entering the UK: a proportionate balance had been struck by the Secretary of State under Article 10(2) between the public interest aim of preventing disorder and the applicant's freedom of expression. Of particular relevance to the Court of Appeal in coming to the conclusion that it did, was the belief that a possible margin of appreciation should be shown to the Secretary of State in deciding whether his failure to grant the applicant a visa to enter the UK was unlawful. The court in fact found a margin of appreciation for several reasons: the ECtHR had identified the control of immigration as being an area where the executive had particular competence, ${ }^{106}$ the decision was personally taken by the Minister, ${ }^{107}$ the Minister was far better placed to reach an informed decision as to the likely consequences of admitting the applicant to the UK than was the court, ${ }^{108}$ the Minster was democratically accountable for his decision, ${ }^{109}$ and finally the very limited extent

\footnotetext{
104 The Court of Appeal, [2002] EWCA Civ 297, [2002] 3 WLR 1080, ruled that the censorship - for the protection of public morals - had constituted a disproportionate infringement of Article 10 of the ECHR. For example, Simon Brown LJ (as he then was) said (para 57): "Was there a pressing social need to ban this broadcast? I have reached the clear conclusion that there was not. Disturbing, perhaps shocking, though the images on this video undoubtedly are, they represent the reality, the actuality, of what is involved in the abortion process. To campaign for the prohibition of abortion is a legitimate political programme. The pictures are in a real sense the message. Words alone cannot convey (particularly to the less verbally adept) the essentially human character of the foetus and the nature of its destruction by abortion. This video provides a truthful, factual and, it is right to say, unsensational account of the process." The ruling of the House of Lords has provoked much academic criticism, see, for example, Rowbottom (2003) and Barendt (2003) who describes it as "a bad day for free speech" (p.591).

105 [2002] EWCA Civ 606, [2002] QB 1391.

${ }^{106}$ Ibid., para 71.

${ }^{107}$ Ibid., para 72.

${ }^{108}$ Ibid., para 73.

${ }^{109}$ Ibid., para 74.
} 
to which the right of freedom of expression of the applicant had been restricted. ${ }^{110}$

It is submitted, therefore, that the courts' employment of the proportionality test means that they are not always reviewing merits: when examining qualified rights of the ECHR, judges may have to apply the margin of appreciation principle. That is, the public interest will sometimes outweigh the private right of the applicant to such a degree that the standard of proportionality does not always involve a court in merits-review. Furthermore, the test itself, as identified by Maurice Kay LJ in the Court of Appeal in Regina (Clays Lane Housing Co-operative) v. Housing Corporation, ${ }^{111}$ does not require a decision that is the least intrusive of Convention rights. To this end, reviewing courts might accord the executive a fair degree of latitude in their administrative decision-making, even to the point that they are not employing low standards of intervention. How then do these findings about the possible high standards of proportionality being applied - either by reference to the context in which a particular qualified right of the ECHR arises or the means by which the test is employed - affect the legitimacy of the merits-review cases identified in the earlier article in this study?

As an interim conclusion these findings are welcomed by the author, and maybe by other "political constitutionalists". ${ }^{112}$ However, the fact remains, cases were found in the previous article in this study where the courts did adopt low standards of irrationality. Some of these were cases where the margin of appreciation principle did not arise as rights of the applicant, if they were so affected, could not have been assessed in terms of justifying infringements on the grounds of the public interest. Moreover, what would be the legitimate standard of review if the courts were examining breaches of other Articles of the ECHR which do not allow for a proportionality type of approach such as the absolute and non-derogable right enshrined in Article 3, the prohibition on torture or inhuman or degrading treatment

\footnotetext{
${ }^{110}$ Ibid., para 77.

111 [2004] EWCA Civ 1658, [2005] 1 WLR 2229.

112 See footnote 12. However, Wadham et al (2007) note that the Court of Appeal's ruling in Farrakhan was a "particularly wide margin of appreciation" (p.198). In this respect perhaps Farrakhan should be seen as exceptional, thus the author maybe should have less cause for optimism than he shows in the main text.
} 
or punishment? ${ }^{113}$ Would a low standard of intervention be constitutionally justifiable in these situations? What would be the legitimate standard of review if a court was not necessarily assessing the lawfulness of executive action by reference to a particular Article of the ECHR under s.6(1) of the HRA but was considering either the "interpretative obligation" under s.3 of the HRA or a declaration of incompatibility under s.4(2) of the HRA? For reasons of space these further questions about the constitutionality of merits-review in cases where, for example, unqualified rights were at issue cannot meaningfully be undertaken here so are reserved for the next article in this study.

\section{$\underline{\text { Conclusion }}$}

Traditional public law doctrine dictates that when the executive is acting unlawfully, it should have exceeded the expressed and implied limits of the power conferred on it by the Legislature. Parliament grants discretionary powers to the executive as a constitutional acknowledgement that because of its knowledge and experience it is best placed to act. By providing an administrative decision-maker with a degree of latitude to decide upon several courses of action within a particular discretion, the high standards of intervention inferred from the many definitions of irrationality recognise this constitutional norm. ${ }^{114}$ A reviewing court should therefore interfere under this head of challenge only when an administrative decision was not within a range of options available to a reasonable decision-maker. This doctrine is, of course, not observed in practice on every occasion. Previously the author established that the courts had in fact held arguably rational administrative decisions to be unlawful, thus adopting low standards of irrationality as a basis for intervention.

\footnotetext{
${ }^{113}$ See, for example, Ireland v. United Kingdom (1978) 2 EHRR 25, para 163. The statement that Article 3 does not allow a proportionality type of approach is not strictly true: see footnote 84 for an interim discussion of the applicability of proportionality to this article of the ECHR.

${ }^{114}$ For example, in the GCHQ case [1985] AC 374 Lord Diplock described an irrational decision as a decision which was (p.410): "so outrageous in its defiance of logic and accepted moral standards that no sensible person who had applied his mind to the question to be decided could have arrived at it”. Similarly, Lord Scarman in the House of Lords in Nottinghamshire County Council v. Secretary of State for the Environment [1986] AC 240 used forceful language to define irrationality (p.248): “.... pattern of perversity or absurdity of such proportions that the guidance could not have been framed by a bona fide exercise of political judgment on the part of the Secretary of State.”
} 
The purpose here has been to reassess the constitutionality of some of these low standards of irrationality which were found in the earlier article of this study.

Considering the legitimacy of a review of merits based upon the manner of review, it has been questioned whether Simon Brown LJ in Ex parte Phoenix Aviation may have been justified in adopting a low standard of intervention because he was in fact employing the proportionality principle as a substitute for irrationality. The proportionality test has been adopted widely by the UK courts in matters of EC Law since the European Communities Act 1972 came into force in January 1973. Nevertheless, its case for greater recognition in English administrative law has been strengthened since October 2000 with the coming into force of the HRA and the incorporation of Convention rights into domestic law. In these terms it is difficult to doubt the constitutionality of a review of merits where proportionality has been adopted under the auspices of irrationality. Similarly, Laws J in Ex parte B may have been acting legitimately as his engagement in a review of merits was possibly due to another acceptable basis for judicial intervention, the adoption of the "hard look" test. Furthermore, the context of these two cases cannot be ignored. Since fundamental rights were at issue on both occasions, again, the constitutionality of these reviews of merits is difficult to ignore. The coming into force of the HRA, and especially the obligation imposed on the courts by s. 3 to interpret primary and secondary legislation in any proceedings in line with Convention rights "so far it is possible to do so”, strengthens their case for legitimacy still further.

What then are the consequences of this constitutional repositioning of the courts? Of course, public law espouses the principle of the separation of powers between the organs of the state. Those individuals who contend, for whatever reason, that a review of merits is legitimate surely do not desire a complete merger of the judicial and executive functions: there must still be a threshold where a reviewing court is not permitted to overstep?

In the subsequent article in this study the author will identify such a limit to judicial review, "substitution of judgment". He will, however, encounter problems in the practical application of this limit, some commentators, for example, having confused it with other principles like proportionality. Since this article has found proportionality review to be in fact constitutionally justifiable, there is, therefore, a worrying conclusion to be drawn from this confusion: the possible inability to classify 
any low standards of intervention as being illegitimate (at least) by reference to the manner of review adopted.

Finding the manner of review to be therefore inappropriate as a means of identifying unacceptable grounds for judicial intervention, the author prefers in this later article to classify low standards of irrationality by reference to context. However, this, too, will pose similar problems in that constitutional justifications for intervention such as breaches of basic rights invariably overlap with unconstitutional ones such as matters of policy. In the long term, therefore, the third article in this study will highlight a fundamental inability to identify a zone of judicial intervention where the courts are excluded. If traditionalists within public law are concerned about the wider acceptance of merits-review by the courts, as identified by the author in the previous article, the lack of any acceptable limits to judicial review signals a serious constitutional shift in the balance of power between the executive and the unelected courts. Are we therefore witnessing a fusing of the judicial and executive roles? If so, for reasons of democracy, the ultimate conclusion of this three article study will be the demand for the courts to return to more orthodox standards of judicial intervention.

\section{References}

Allan, Trevor. 1993. Law, liberty, and justice. Oxford: Clarendon Press

Allan, Trevor. 1988. Pragmatism and theory in public law. Law quarterly review 104: 422-447.

Arnold, Graham. 2006. The Human Rights Act - has it made a difference? Student law review 49: 16-19.

Barber, Nicholas. 2001. Prelude to the separation of powers. Cambridge law journal 60: 59-88.

Barendt, Eric. 1995. Separation of powers and constitutional government. Public law: 599-619.

Barendt, Eric. 2003. Free speech and abortion. Public law: 580-591.

Clayton, Richard. 2007. The Human Rights Act six years on: where are we now? European human rights law review: 11-26.

Craig, Paul. 1994. Administrative law. London: Sweet and Maxwell. 
Craig, Paul. 1997. The impact of community law on domestic public law. In Administrative law facing the future: old constraints and new horizons, eds. Peter Leyland and Terry Woods, 271-296. London: Blackstone Press.

Craig, Paul. 1998. Unreasonableness and proportionality in UK law. Conference paper at the Institute of European Law, The University of Birmingham, on 20th March.

Craig, Paul. 1999. Unreasonableness and proportionality in UK law. In The principle of proportionality in the laws of Europe, ed. Evelyn Ellis, 85-106. Oxford: Hart Publishing.

Craig, Paul. 2001. The courts, the Human Rights Act and judicial review. Law quarterly review 117: 589-603.

De Burca, Grainne. 1997. Proportionality and Wednesbury unreasonableness: the influence of European legal concepts on UK law. European public law 3: 561-586.

De Smith, Stanley, Harry Woolf and Jeffrey Jowell. 1999. Principles of judicial review. London: Sweet and Maxwell.

Dennis, Ian. 2006. Reconsidering the Human Rights Act. Criminal law review: 577578.

Elliott, Mark. 2001. Scrutiny of executive decisions under the Human Rights Act 1998: exactly how ‘anxious’? Judicial review: 166-176.

Elliott, Mark. 2002. The Human Rights Act 1998 and the standard of substantive review. Judicial review: 97-109.

Elliott, Mark. 2006a. Legitimate expectations and the search for principle: reflections on Abdi and Nadarajah. Judicial review: 281-288.

Elliott, Mark 2006b. Legitimate expectations: procedure, substance, policy and proportionality. Cambridge law journal 65: 254-256.

Feldman, David. 2005. Proportionality and discrimination in anti-terrorism legislation. Cambridge law journal 64: 271-273.

Fordham, Michael. 1997. Judicial review handbook. $2^{\text {nd }}$ ed. London: John Willey Press.

Fordham, Michael. 2002. Common law proportionality. Judicial review: 110-123.

Fordham, Michael. 2007. Wednesbury. Judicial review: 266-268.

Fordham, Michael. 2008. Judicial review: the future. Judicial review: 66-68.

Gee, Graham. 2008. The political constitutionalism of JAG Griffith. Legal Studies 28: 20-45.

Griffith, John. 1979. The political constitution. Modern law review 42: 1-21. 
Griffith, John. 1985. Judicial decision-making in public law. Public law: 564-582.

Griffith, John. 1997. The politics of the judiciary. $5^{\text {th }}$ ed. London: Fontana Press.

Griffith, John. 2000. The brave new world of Sir John Laws. Modern law review 63: 159-176.

Harden, Ian and Norman Lewis. 1986. The noble lie: the British constitution and the rule of law. London: Hutchison.

Harlow, Carol and Richard Rawlings. 1984. Law and administration. London: Weidenfield and Nicholson.

Hickman, Thomas. 2004. The reasonableness principle: reassessing its place in the public sphere. Cambridge law journal 63: 166-198.

Hickman, Thomas. 2007. Proportionality: comparative law lessons. Judicial review: 31-55.

Hilson, Christopher. 2003. The Europeanization of judicial administrative law: judicial review and convergance. European public law 9: 125-145.

Hoffman, Lord. 2002. The separation of powers. Judicial review: 137-145.

Hunt, Murray. 1997. Using human rights law in English courts. Oxford: Hart Publishing.

Irvine, Lord. 1996. Judges and decision-makers: the theory and practice of Wednesbury review. Public law: 59-78.

Irvine, Lord. 1998. The development of human rights in Britain. Public law: 221-236.

Irvine, Lord. 2003. The impact of the Human Rights Act: Parliament, the courts and the Executive. Public law: 308-325.

James, Rhoda, and Diane Longley. 1995. Judicial review and tragic choices: Ex Parte B. Public law: 367-373.

Joint Committee on Human Rights. 2008. A bill of rights for the UK? $29^{\text {th }}$ Report of 2007/08 Session, $10^{\text {th }}$ August.

Jowell, Jeffrey. 1996. Is proportionality an alien concept? European public law 2: 401411.

Jowell, Jeffrey. 2000. Beyond the rule of law: towards constitutional judicial review. Public law: 671-683.

Jowell, Jeffrey, and Anthony Lester. 1987. Beyond Wednesbury: substantive principles of administrative law. Public law: 368-382. 
Jowell, Jeffrey and Anthony Lester. 1988. Proportionality: neither novel nor dangerous. In New directions in judicial review, eds. Jeffrey Jowell and Dawn Oliver. 51-72. London: Stevens.

Knight, Christopher. 2007. The test that dare not speak its name: proportionality comes out of the closet. Judicial review: 117-121.

Laws, John. 1995. Law and Democracy. Public law: 72-93.

Lester, Anthony. 2001a. Developing constitutional principles of public law. Public law: 684-694.

Lester, Anthony. 2001b. The relevance of comparative constitutional case law. Judicial review: 13-19.

McAuslan, Patrick. 1971. The plan, the planners and the lawyers. Public law: 247263.

McAuslan, Patrick. 1983. Administrative law, collective consumption, and judicial policy. Modern law review 46: 1-19.

McAuslan, Patrick, and McEldowney, John. 1985. Law, legitimacy and the constitution. London: Sweet and Maxwell.

Miles, John. 2000. Standing under the Human Rights Act 1998: theories of rights enforcement and the nature of public law adjudication. Cambridge law journal 59: 133167.

Montesquieu, Charles. 1994. De l'esprit des lois. Paris: Ceres.

Morton, James. 2006. The Human Rights Act 1998: time for a substantial rethink? Journal of Criminal Law 70: 273-275.

Oliver, Dawn. 1986. Is the ultra vires rule the basis of judicial review? Public law: 543-569.

Poole, Thomas. 2005. Legitimacy, rights and judicial review. Oxford journal of legal studies. 25: 697-725.

Poole, Thomas. 2007. Tilting at windmills? Truth and illusion in 'the political constitution'. Modern law review 70: 250-277.

Rivers, Jonathan. 2006. Proportionality and variable intensity of review. Cambridge law journal 65: 174-207.

Rowbottom, Jacob. 2003. Article 10 and election broadcasts. Law quarterly review 119: 553-557.

Sedley, Stephen. 1997. The common law and the constitution. London review of books 19(9): 8-11. 
Steyn, Lord. 2002. The case for a supreme court. Law quarterly review 118: 382-396.

Squires, David. 2000. Judicial review of the prerogative after the Human Rights Act. Law quarterly review 116: 572-575.

Taggert, Michael. 2004. Reinventing administrative law. In Public law in a multilayered constitution, eds. Nicholas Bamforth and Peter Leyland, 311-335. Oxford: Hart Publishing.

Tomkins, Adam. 2002. In defence of the political constitution. Oxford journal of legal studies 22: 157-175.

Tomkins, Adam. 2003. Public Law. Oxford: Oxford University Press.

Tomkins, Adam. 2004. What is Parliament for? In Public law in a multi-layered constitution, eds. Nicholas Bamforth and Peter Leyland, 53-78. Oxford: Hart Publishing.

Tomkins, Adam. 2005a. Readings of A v. Secretary of State for the Home Department. Public law: 259-266.

Tomkins, Adam. 2005b. Our republican constitution. Oxford: Hart Publishing.

Tomkins, Adam. 2007. Professor Tomkins' house of mavericks: a reply. Public law: 33-39.

Turner, Ian. 2006. Judicial review, irrationality and the review of merits. Nottingham law journal 15(2): 37-50.

Wadham, John et al. 2007. Blackstone's guide to the Human Rights Act 1998. $4^{\text {th }}$ ed. Oxford: Oxford University Press.

Wong, Garreth. 2000. Towards the nutcracker principle: reconsidering the objections to proportionality. Public law: 92-109. 